\title{
Delineation of kimberlite lithofacies at the D/K1 Pipe, Letlhakane, Botswana
}

\author{
S.K. Trickett ${ }^{1,3}$, A.P. Jones ${ }^{1}$, and M. Field ${ }^{2}$ \\ ${ }^{1}$ Department of Earth Sciences, University College London, London, UK \\ ${ }^{2}$ DiaKim Consulting Limited, Wells, UK \\ ${ }^{3}$ Schlumberger Information Solutions, Victory House, Churchill Court, Crawley, UK (STrickett@slb.com)
}

Introduction

Kimberlite pipes frequently host several texturally distinct types of volcaniclastic kimberlite or kimberlite lithofacies (Trofimov, 1970; Hawthorne, 1975; Dawson, 1980; and Clement and Reid, 1989). Characterization of individual lithofacies is not always easy and therefore there is a high level of uncertainty in geological models of producing mines. We investigated a number of ways to facilitate the identification and delineation of kimberlite lithofacies at the D/K1 pipe, Letlhakane, Botswana.

\section{Geology}

The $\mathrm{D} / \mathrm{K} 1$ pipe is the larger of two kimberlite pipes at the Letlhakane Mine that erupted through the Zimbabwe Craton 93 Ma (Siefenhofer et al., 1997; Denies and Harris, 2004). The Letlhakane Mine is $\sim 200 \mathrm{~km}$ west of Francistown in the Boteti District of Central Botswana. The host rock geology is a simple, layer-cake sequence comprised of Archaen basement granites and gneisses overlain by Karoo mudstones, silts, coal and sands with an uppermost unit of Stormberg flood basalt. 4-10 m of Cretaceous to recent Kalahari sediments and calcrete overlay the basalt.

The D/K1 kimberlite pipe was divided into four kimberlite lithofacies based on diamond grade and geological observation during the mid-1990s (Figure 1). Differentiation between the lithofacies became increasingly difficult over time, indicating a revision of the model was required. The revised pipe model was proposed after detailed drill core logging supported by petrographic study. Six major volcaniclastic kimberlite units were identified some comprising of sub-units or lithofacies associations that were believed to have related emplacement histories. A summary of each major unit is given in Table 1.

\begin{tabular}{|c|c|c|c|c|c|c|}
\hline & VK1 & DVK & PVK & SVK & BBR & CK \\
\hline Colour & Dark grey & Very dark grey & Pale-dark grey & Pale grey-brown & $\begin{array}{l}\text { Light brown- } \\
\text { grey }\end{array}$ & $\begin{array}{l}\text { Very dark grey- } \\
\text { black }\end{array}$ \\
\hline $\begin{array}{l}\text { Ol Content } \\
(\text { vol } \%)\end{array}$ & $30-40$ & 50 & 30 & 30 & $10-20$ & 60 \\
\hline $\begin{array}{l}\text { Av. ol size } \\
(\mathrm{mm})\end{array}$ & 3 & 2 & 4 & 5 & 3 & 3 \\
\hline Ol alt. & $\begin{array}{l}\text { Completely ser- } \\
\text { pentinised }\end{array}$ & $\begin{array}{l}\text { Fresh- } \\
\text { serpentinised }\end{array}$ & $\begin{array}{l}\text { Completely ser- } \\
\text { pentinised }\end{array}$ & $\begin{array}{l}\text { Completely ser- } \\
\text { pentinised }\end{array}$ & $\begin{array}{l}\text { Completely ser- } \\
\text { pentinised }\end{array}$ & $\begin{array}{l}\text { Fresh with Ca- } \\
\text { rich rims }\end{array}$ \\
\hline $\begin{array}{l}\text { Av. lithic } \\
\text { content } \\
(\mathrm{vol} \%)\end{array}$ & 12 & 10 & 8 & 15 & $60-\geq 90$ & 7 \\
\hline $\begin{array}{l}\text { Lithic frag- } \\
\text { ment size; } \\
\text { max. av. }\end{array}$ & $10 \mathrm{~mm}, 2 \mathrm{~mm}$ & $20 \mathrm{~mm}, 2 \mathrm{~m}$ & $300 \mathrm{~mm}, 10 \mathrm{~mm}$ & $20 \mathrm{~mm}, 2 \mathrm{~m}$ & $200 \mathrm{~mm}, 10 \mathrm{~m}$ & $100 \mathrm{~mm}, 10 \mathrm{~mm}$ \\
\hline Lithic Alt. & $\begin{array}{l}\text { Few alteration } \\
\text { haloes }\end{array}$ & $\begin{array}{l}\text { Metamorphosed } \\
\text { and alteration } \\
\text { haloes }\end{array}$ & $\begin{array}{l}\text { Metamorphosed } \\
\text { (?) }\end{array}$ & Unaltered & $\begin{array}{l}\text { Unaltered- } \\
\text { oxidised }\end{array}$ & Metamorphosed \\
\hline Texture & $\begin{array}{l}\text { Ghost lapilli, } \\
\text { pseudo-pelletal }\end{array}$ & $\begin{array}{l}\text { Ghost lapilli, } \\
\text { pseudo-pelletal }\end{array}$ & $\begin{array}{l}\text { Pelletal and ju- } \\
\text { venile lapilli }\end{array}$ & $\begin{array}{l}\text { Pelletal and ju- } \\
\text { venile lapilli }\end{array}$ & $\begin{array}{l}\text { Ghost lapilli } \\
\text { and rare pelletal } \\
\text { lapilli }\end{array}$ & $\begin{array}{l}\text { Coherent, non- } \\
\text { fragmental }\end{array}$ \\
\hline $\begin{array}{l}\text { IM or GM } \\
\text { phase }\end{array}$ & $\begin{array}{l}\text { Fine microlites } \\
\text { and serpentine }\end{array}$ & $\begin{array}{l}\text { Coarser micro- } \\
\text { lites, serpentine } \\
\text { and rare calcite }\end{array}$ & $\begin{array}{l}\text { V. fine-grained } \\
\text { microlites and } \\
\text { serpentine }\end{array}$ & $\begin{array}{l}\text { V. fine-grained } \\
\text { microlites, ser- } \\
\text { pentine, calcite } \\
\text { and phlogopite }\end{array}$ & $\begin{array}{l}\text { Serpentine and } \\
\text { microlites }\end{array}$ & $\begin{array}{l}\text { calcite, serpen- } \\
\text { tine, oxides and } \\
\text { phlogopite }\end{array}$ \\
\hline Structure & $\begin{array}{l}\text { Massive to } \\
\text { crudely layered }\end{array}$ & $\begin{array}{l}\text { Massive to } \\
\text { crudely layered }\end{array}$ & $\begin{array}{l}\text { Massive to } \\
\text { crudely layered }\end{array}$ & $\begin{array}{l}\text { Massive to } \\
\text { crudely layered }\end{array}$ & $\begin{array}{l}\text { Massive to } \\
\text { crudely layered }\end{array}$ & Massive \\
\hline
\end{tabular}

Table 1: Summary table of the main characteristics of the major D/K1 lithofacies; VK1, DVK, PVK, SVK, BBR and CK. (Ol olivine; IM - interclast matrix; GM - groundmass; Alt - alteration; Av. average; Max. - maximum; v - very; microlites - diopside). 


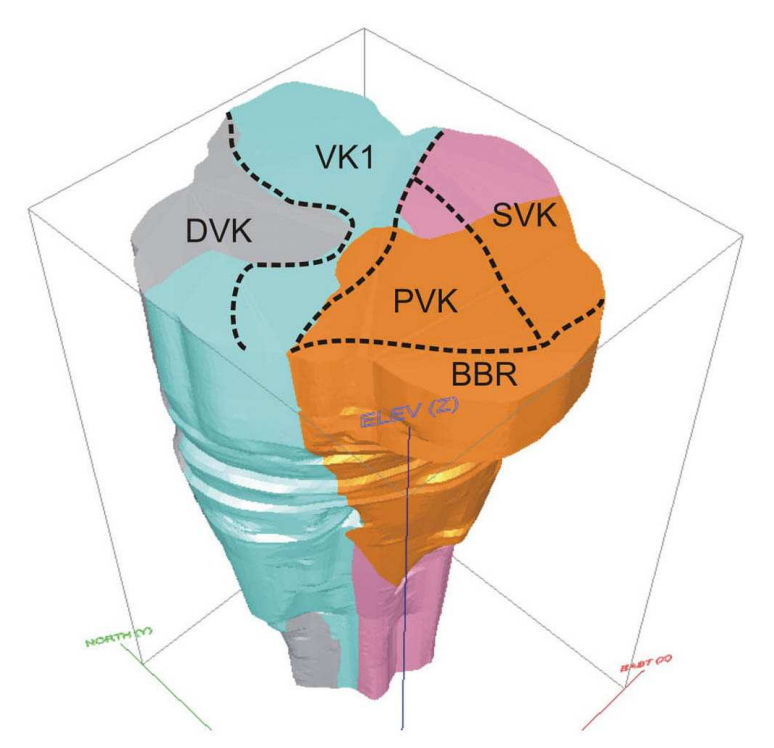

Figure 1: Model of the D/K1 kimberlite pipe with new facies overlying the old model

\section{Spinel petrography}

Groundmass spinel compositions were analyzed to determine how well they could fingerprint the lithofacies identified from field and thin section study. In addition, we wanted to understand how their compositional and textural variations related to petrogenetic and physiochemical processes.

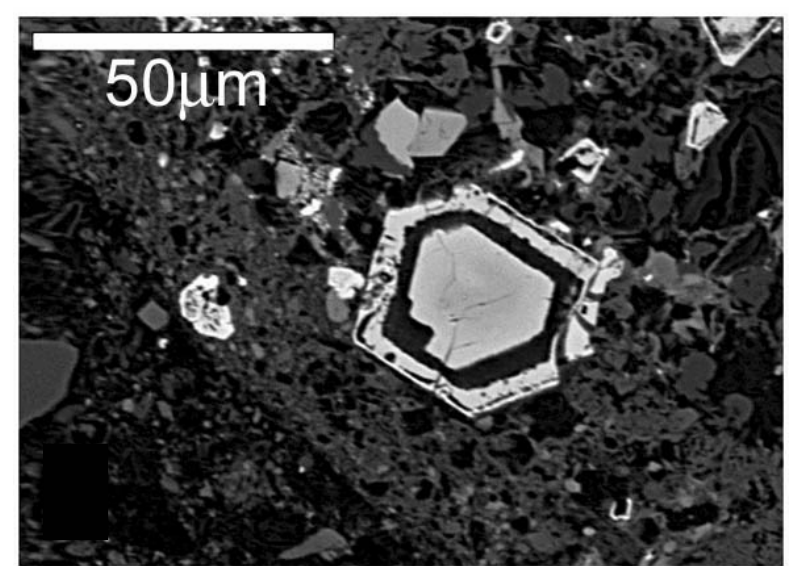

Figure 2 - Back scattered electron image of atoll spinel within a juvenile lapillus.

$\mathrm{D} / \mathrm{K} 1$ groundmass spinels define a compositional trend of decreasing $\mathrm{Cr}$ and $\mathrm{Al}$ with increasing $\mathrm{Ti}$ and $\mathrm{Fe}^{3+}$ (Figure 3). This is consistent with the 'kimberlite trend' of Barnes \& Roeder (2001) and Magmatic Trend 1 of Mitchell (1986). It is interpreted as the effect of cocrystallization of chromite with olivine at a constant composition and constant temperature (Irvine 1967). The Letlhakane D/K1 groundmass spinels are notably Ti-rich and very few analyses have $<5 \mathrm{wt} \% \mathrm{TiO}_{2}$. The groundmass assemblage was dominated by perovksite which also suggests a strong influence of $\mathrm{Ti}$ on the kimberlite. However, pure magnetite was only found in one grain out of $>700$ analyses. It is possible that the liquidus phases were continually saturated in $\mathrm{Ti}$ and therefore Ti-free magnetite never stabilized on the liquidus. This is probably a direct result of a Tienriched melt.

We were looking for lithofacies-specific trends. Although there was a degree of overlap in compositions from all lithofacies, the locus of each analyzed set was subtly set apart. Core compositions were shifted along the $\mathrm{Fe}^{2+} / \mathrm{Fe}^{2+}+\mathrm{Mg}$ axis by lithofacies; compositions from PVK were the most $\mathrm{Mg}$ rich, followed by SVK, VK1, BBr1 ${ }^{*}$ and spinels from the DVK were the most Fe-rich. The subtle distinction in $\mathrm{Fe}^{2+} / \mathrm{Fe}^{2+}+\mathrm{Mg}$ ratios between lithofacies is significant because it reflects the primitive composition of the melt and may show that spinels crystallized from melts with different starting compositions. This was also demonstrated in hypabyssal kimberlite within the root zone at the De Beers pipe by Pasteris (1983) and the Wesselton pipe by Shee (1985).
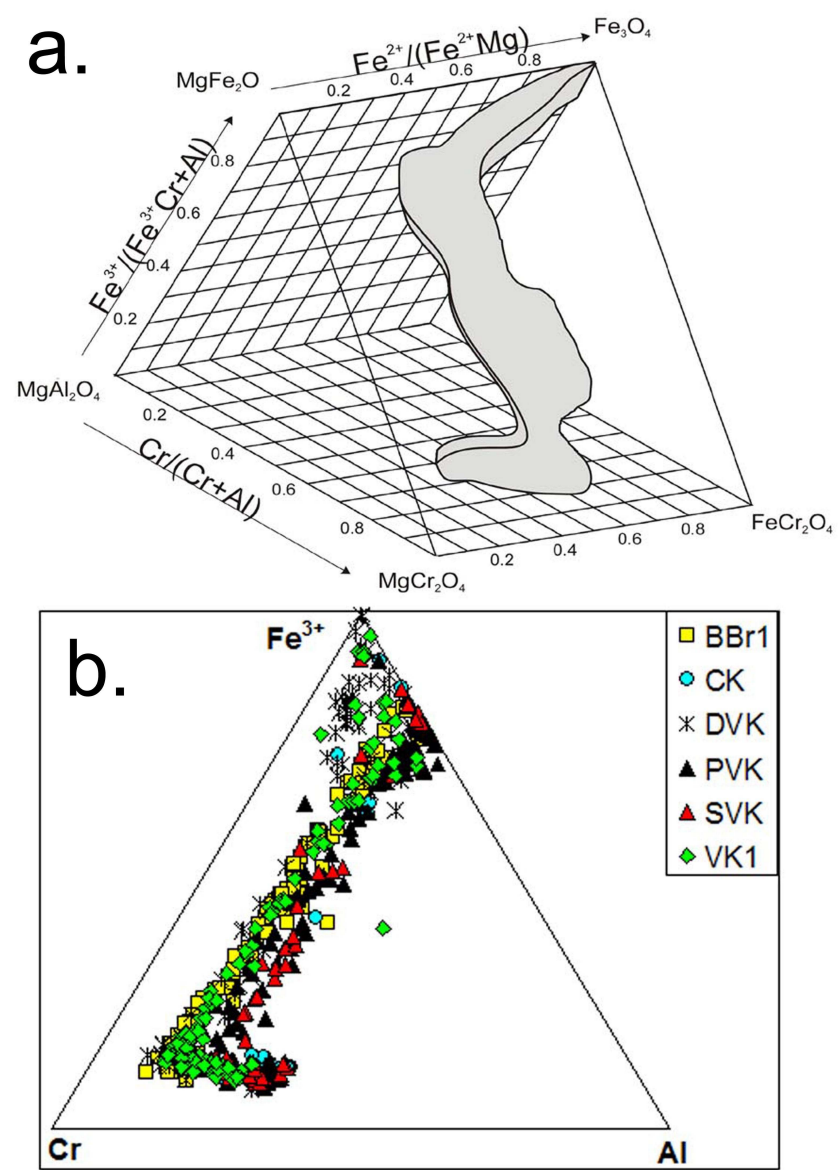

Figure 3: (a) Oxidised spinel prism illustrating the locus ( $90 \%$ of analyses) of all D/K1 spinel compositions. (b) Triangular plot of $\mathrm{Fe}^{3+}, \mathrm{Cr}^{3+}$ and $\mathrm{Al}^{3+}$.

Atoll spinels (Figure 2) were most developed and well preserved in juvenile lapilli. One sample from the PVK lithofacies contained atoll spinels with different compositional trends from two separate lapilli. We believe this suggests that the lithofacies contains spinels that were derived from at least two batches of erupted magma, implying multiple eruptive phases.

\footnotetext{
${ }^{*} \mathrm{BBr} 1$ is a subset of the VK1 lithofacies
} 


\section{Bulk rock geochemistry}

The bulk rock geochemistry of a wide range of samples from the D/K1 pipe was analyzed by XRF. Our aim was to test whether the geochemistry of volcaniclastic kimberlite could be used to delineate the D/K1 lithofacies. Previous work by Nowicki (1993) showed that this method had succeeded in the past; we wanted to extend this study to the entire pipe and examine the results using multivariate statistics to group the data into distinct clusters.

a.
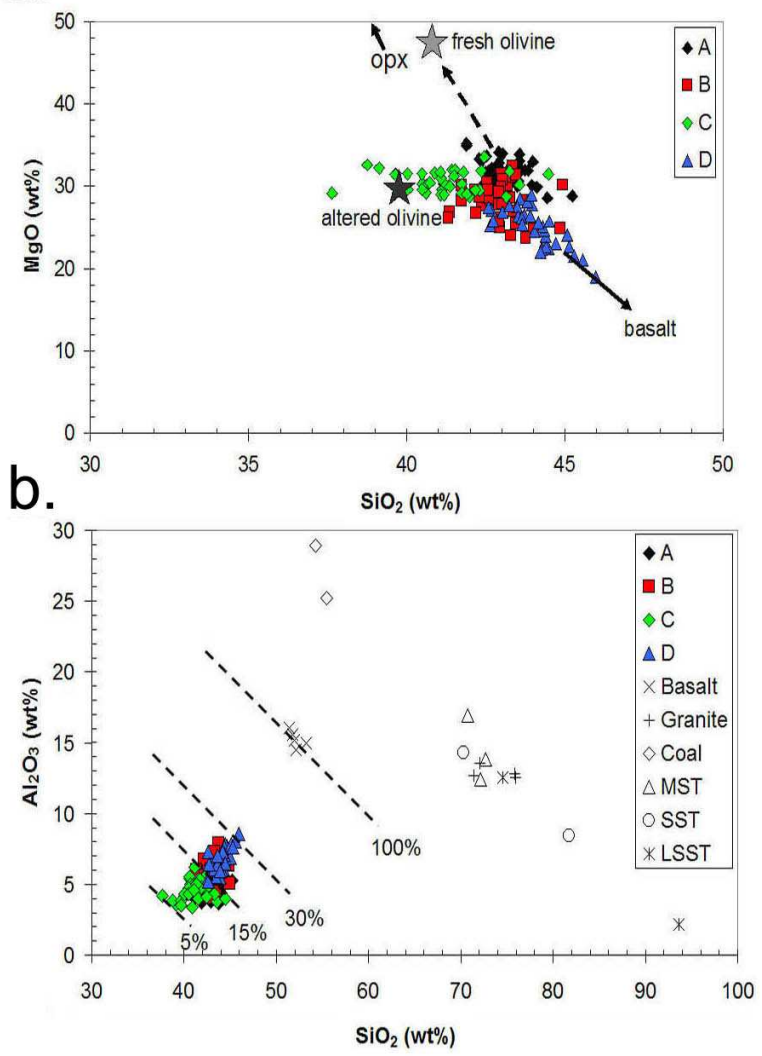

Figure 4: Geochemistry results (a) $\mathrm{MgO}$ and (b) $\mathrm{Al}_{2} \mathrm{O}_{4}$ versus $\mathrm{SiO}_{2}$ with fresh and altered olivine and basalt compositions in (a) and percentage of country rock waste indicated in (b).

The analyzed samples were clustered into four major groups and subgroups by statistical processing. The major geochemical influences that clustered the samples were from (i) mantle-derived components, predominantly $\mathrm{Ni}$ and $\mathrm{MgO}$ consistent with olivine accumulation, and $\mathrm{Cr}$ from chrome-spinel accumulation (ii) magma-derived components, predominantly incompatible trace elements, $\mathrm{CaO}, \mathrm{K}_{2} \mathrm{O}$ and $\mathrm{TiO}_{2}$ representing the last phases to crystallize from the magma, and (iii) crustal-derived $\mathrm{Al}_{2} \mathrm{O}_{3}, \mathrm{Na}_{2} \mathrm{O}$ and to some extent $\mathrm{SiO}_{2}$ (Figure 4b). This illustrated how shallow-level and eruptive processes, including those taking place during the eruption, can geochemically fingerprint the D/K1 kimberlite. This is potentially a quick and powerful tool in delineating kimberlite lithofacies elsewhere.

\section{Conclusion}

The underlying question throughout this study was how well certain geological, mineralogical, petrographic and geochemical indicators could delineate lithofacies at the D/K1 kimberlite pipe. By analyzing the relationship between groundmass spinel and perovskite we also proposed a groundmass crystallization sequence. We have shown from groundmass spinel compositions, core logging, petrographic study, and bulk rock geochemistry that the $\mathrm{D} / \mathrm{K} 1 \mathrm{kimberlite}$ pipe is comprised of multiple, distinct kimberlite lithofacies. These were produced by a dynamic eruptive event that involved repeated episodes of activity which, in some cases, quarried out and mixed with older deposits.

\section{Acknowledgements}

Funding for this research was awarded jointly from the EPSRC and De Beers, while Debswana funded me while I was at Orapa. I would also like to thank the many people who assisted me during my $\mathrm{PhD}$ especially Matthew Field and Adrian Jones for their relentless support and guidance.

\section{References}

Barnes, S. J. \& Roeder, P. L. (2001). The range of spinel compositions in terrestrial mafic and ultramafic rocks. Journal of Petrology, 42(12), 2279-2302.

Clement, C. R. \& Reid, A. M. (1989). In Kimberlite and Related Rocks, Proceedings of the Fourth International Kimberlite Conference Blackwell Scientific Publications. pp. 634-646.

Dawson, J. (1980). Kimberlites and their Xenoliths. Springer Verlag.

Deines, P. \& Harris, J. W. (2004). New insights into the occurrence of ${ }^{13} \mathrm{C}$-depleted carbon in the mantle from two closely associated kimberlites: Letlhakane and Orapa, Botswana. Lithos, 77, 125-142.

Hawthorne, J. B. (1975). Model of a kimberlite pipe. Physics and Chemistry of the Earth, 9, 1-15.

Irvine, T. (1967). Chromian spinel as a petrogenetic indicator. part 2. Canadian Journal of Earth Sciences, 4, 71103.

Mitchell, R. H. (1986b). Kimberlites: Mineralogy, Geochemistry and Petrology. Plenum Press, New York.

Nowicki, T. (1993). The HMA and geochemistry of boreholes LFD3, LFD5 and LFD6 , Letlhakane Mine, Botswana. Technical Report R/93/075, Anglo American Research Laboratories.

Pasteris, J. D. (1983). Spinel zonation in the De Beers kimberlite, South Africa: possible role of phlogopite. Canadian Mineralogist, 21, 41-58.

Shee, S. R. (1985). The petrogenesis of the Wessleton Mine Kimberlite, Kimberly, Cape Province, R.S.A. PhD thesis, University of Cape Town.

Stiefenhofer, J., Viljoen, K., \& Marsh, J. (1997). Petrology and geochemistry of peridotite xenoliths from the Letlhakane kimberlites, Botswana. Contributions to Mineralogy and Petrology, 127, 147-158.

Trofimov, V. S. (1970). On the origin of diamantiferous diatremes. Bulletin of Volcanology, 34, 767-776. 